\title{
ARAŞTIRMA/RESEARCH
}

\section{DOĞUM YAPAN KADINLARIN DOĞUM SONU KONFORU VE ETKİLEYEN FAKTÖRLER}

\section{Fatma BİRGILI*}

\begin{tabular}{ccc}
\hline Alınış Tarihi/Received & Kabul Tarihi/Accepted & Yayın Tarihi/Published \\
19.11 .2018 & 15.09 .2020 & 30.09 .2020 \\
\hline Bu makaleye atıfta bulunmak için/To cite this article: \\
Birgili F. Doğum yapan kadınların doğum sonu konforu ve etkileyen faktörler. Anadolu Hemşirelik ve Sağlık \\
Bilimleri Dergisi, 2020; 23(3): 351-360. DOI: 10.17049/ataunihem.484941
\end{tabular}

Amaç: Araştırma, doğum yapan kadınların doğum sonu konforu ve etkileyen faktörlerin belirlenmesi amacıyla yapılmiştır.

Yöntem: Araştırma ülkemizin batısında bir ĕ̆itim ve araştırma hastanesinin kadın-doğum kliniğinde 406 anne ile yapılmıştır. Araştırma Ocak 2017- Ocak 2018 tarihleri arasında yapılmıştır. Veriler, kişisel bilgi formu ve Doğum Sonu Konfor Ölçeği (DSKÖ) ile toplanmıştır. Veriler sayl, yüzdelik, ortalama, standart sapma, Cronbach Alpha, t testi, Mann-Whitney U testi, Kruskall-Wallis, tek yönlü varyans analizi ile değerlendirilmiştir.

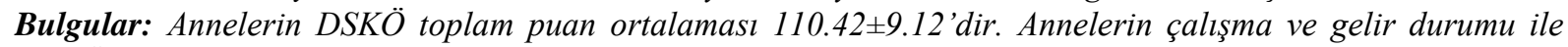
DSKÖ; annelerin aile tipleri, doğumda komplikasyon olmasl, doğum şekli ve doğum sonu anne-bebek ilişkisinin sağlanması ile fiziksel alt boyut; annelerin gelir düzeyi, aile tipleri, gebeliği isteme durumu, doğum sayısı, doğumda komplikasyon olma, doğum şekli ve doğum sonu anne-bebek ilişkisinin să̆lanması durumu ile psikospritüel alt boyut; annelerin gelir düzeyi ve gebeliği isteme durumu ile sosyo-kültürel alt boyut puanları arasında anlaml fark olduğu belirlenmiştir $(p<0.05)$.

Sonuç: Araştırmada annelerin orta düzeyde konfora sahip oldukları belirlenmiştir. Doğum yapan annelerin doğum sonu dönemde konforunu artırabilmek için, hemşirelerin bakım gereksinimlerini belirlemede, annelerin konfor konusunda beklentilerini göz önünde bulundurmaları önerilebilir.

Anahtar kelimeler: Doğum sonu dönem; hemşirelik bakımı; kadın; konfor

ABSTRACT

The Birth of Comfortable Women and The Effective Factors

Aim: The study was conducted to determine the postpartum comfort and the factors affecting the birth of women. Methods: The study was carried out with 406 mothers in a maternity-ward clinic of a training and research hospital in the west of our country. The study was conducted between January 2017 and January 2018. The data were collected by a personal information form and Postpartum Comfort Scale. Data were evaluated by number, percentage, mean, standard deviation, Cronbach Alpha, t test, Mann-Whitney U test, Kruskall-Wallis, one-way variance analysis.

Results: The PCS mean total score of the mothers was 110.42 \pm 9.12 . Working and income status of mothers and PCS; mothers' family types, complication at birth, delivery type and postpartum mother-infant relationship with the physical sub-dimension; the level of income of the mothers, family types, the demand for pregnancy, the number of births, the complication at birth, the mode of delivery and the postpartum mother-infant relationship and psycho-spiritual sub-dimension; There was a significant difference between the income level of the mothers and the demand for pregnancy and socio-cultural sub-dimension scores ( $p<0.05)$.

Conclusion: In the study, it was determined that mothers had moderate comfort. In order to increase the comfort of postpartum mothers during the postpartum period, nurses may be advised to take into account their expectation about comfort in determining nursing care needs.

Keywords: Postpartum period; nursing care; woman; comfort

\footnotetext{
* Sorumlu Yazar: Muğla Sitk1 Kocman Üniversitesi Sağlık Bilimleri Fakültesi Hemşirelik Bölümü (Dr. Öğr.

Üyesi), Orcid ID: 0000-0001-5017-0225, e-posta: fatmab@ mu.edu.tr
} 


\section{GİRIS}

Bir kadının yaşamının en önemli aşamalarından biri olan gebelik ve doğum fizyolojik bir süreçtir. Bu sürecin hiçbir yan etkisi olmaksızın sürdürülmesinde ve sona erdirilmesinde rol oynayan pek çok faktör vardır $(1,2)$. Doğum sonu (DS) dönem; anne, bebek ve aile sağlı̆̆ 1 için uyum, yenilenme dönemi, ayni zamanda bu sürece uyumda yeniliklerin de yaşandığ 1 ve psikolojik-sosyolojik değişikliklerin yaşandığ 1 kriz dönemidir (1,3-6). Bu dönem, yeni bebek sahibi olan kadının günlük yaşam aktivitelerini, yaşam kalitesini, ruh halini ve sosyolojik faktörlerini etkileyen bir süreçtir. DS süreç, annede oluşan fizyolojik değişiklikler, aile yaşamındaki değişimler ve anne ölümlerinin pek çoğunun bu dönemde oluşması bakımından önemlidir. Yapılan araştırmalarda DS dönemde yeni bebek sahibi olan annelerin, hem kendi hem de bebeklerinin bakımında zorlandıkları, bebek beslenmesinde ve bakımında yaşanan stres, memede dolgunluk, çatlak, enfeksiyon vb. oluşan sorunlarla karşılaştıkları, annenin yetememe endişesi, anneliğe uyumda yaşanan korkular, doğum sonu kanama, puerperal enfeksiyon gibi sorunlar yaşadıkları belirlenmiştir (7-9). DS dönemde karşı karşıya kalınan problemler ilk zamanlarda daha çok görülmekle birlikte, altı haftaya ya da bir yıl kadar devam eden problemlerle de karşılaşılmaktadır $(10,11)$. Bunun yanı sıra anksiyete ve cinsel problemler, aile içi değişimler, evdeki rutin işleri tekrar yapmaya başlama, bebek bakımına sorumluluk alma, eş ile ilişkiler, bebek bakımı nedeniyle uykuda bozulma ve yorgunluk gibi faktörler de annenin yaşam kalitesini olumsuz etkileyebilmektedir $(12,13)$. Annenin DS dönem sürecinde uyumunun sağlanmasında, anne sütünün erken başlaması ve devam etmesinde, anne bebek ilişkisinin sağlıklı olmasında, iyileşmenin kısa sürede sağlanmasında, oluşabilecek risk faktörlerinin önlenmesinde anne ve bebeğe verilecek bakımda DS konfor önemlidir. Anne DS ağrı, kanama, hijyen, beslenme, mobilizasyon ve bebek bakımı konusunda desteklenirse bebeğin ihtiyaçlarını karşılamada daha yeterli olacaktır. Bu bakımın verilmesinde ebe ve hemşirelerin önemli sorumlulukları vardır $(1,14)$. Anne ve bebeğe hemşirelik/ebelik bakımının sağlanması, annenin DS dönemine uyumunu kolaylaştırmada, bireysel gereksinimleri ortaya koymak ve DS dönemde konforu artırmaya yönelik planlı girişimleri uygulamak annenin bireysel bakım kalitesi, yaşam kalitesi ve memnuniyeti için veri toplamak açısından büyük önem taşımaktadır (2,14-16).
"Konfor kuramı" Katharine Kolcaba tarafindan 2003 yılında geliştirilmiş olup, hemşirelik uygulamalarında bakım alıciların sorunlarının daha sistematik bir şekilde görülebilmesi ve kolay plan yapılabilmesi açısından önemlidir. Konfor kuramına göre konfor; "fiziksel, sosyokültürel, psikospiritüel ve çevresel boyutta ortaya çıkan sorunların ferahlama, rahatlama ve sorunların üstesinden gelme" olarak üç düzeyde karşılanması olarak açıklanır. Fiziksel konfor; bedensel duyular ve vücudun fizyolojik olarak işleyişle konforu içine alır. Örneğin homeostatik denge; sıv1 elektrolit dengesi, kan ve oksijen satürasyonu dengesi vb. durumlar fiziksel konforu etkiler (16-18). Psiko-spritüel konfor; mental, emosyonel, spritüel bileşenlerden oluşmaktadır. Örneğin banyo, masaj, ağız bakımı yapmak, ziyaretçilere izin vermek, temas, hastayı bakımı konusunda cesaretlendirmek ve huzuru sağlamak psikospiritüel konforu destekleyen faktörleri etkileyebilir $(16,18)$. Çevresel konfor; bireyin içinde bulunduğu ortamın 1şık, ses, renk, sıcaklık, koku, refah, manzara, havalandırma, mobilyalar vb. gibi faktörlerin birey üzerine etkilerini içine alır $(16,18)$. Sosyokültürel konfor; bireyin aile ve diğer sosyal kurumlarla ilişkilerini içeren faktörlerdir. Örneğin gelenekler, kurallar, kanunlar ve dinsel faktörler bu konforu etkiler $(16,18)$. Kuramda temel hedef; hastanın konforunun sağlamasıdır (19).

DS dönemde yeni doğum yapan annelerin konfor durumlarının, ihtiyaçlarının ve bu dönemde yaşadığı problemlerin belirlenmesi, sorunların çözümü bakımından oldukça önem arz etmektedir (16). Ülkemizde DS konforun önemi ve etkileyen faktörlerle ilgili sınırlı sayıda çalışma yapılmıştır $(1,14,20,21)$. DS dönemde bireyin tüm ihtiyaçları göz önüne alınarak sağlıklı bir anne, bebek, aile ilişkisi için gerekli olan rahatlığın sağlanması oldukça önemlidir.

\section{AMAÇ}

$\mathrm{Bu}$ çalışma kadınların doğum sonu konforunu etkileyen faktörleri belirlemek amacıyla yapılmıştır.

\section{GEREÇ VE YÖNTEM}

Araştırmanın Türü ve Yapıldı̆̆ı Yer: Araştırma kesitsel olarak planlanmıştır. $\mathrm{Bu}$ araştırma ülkemizin batısında bir eğitim ve araştırma hastanesinin kadın doğum kliniğinde Ocak 2017- Ocak 2018 tarihleri arasında yapılmıştır.

Araştırmanın Evren ve Örneklemi: Araştırmanın evrenini, kadın doğum servisinde bir yıl içinde sezaryen ve vajinal doğum yapan 
kadınlar oluşturmuştur. Hastaneden kadın doğum kliniğinde doğum yapan ve doğum sonras1 sağlıklı bebeğe sahip annelerin sayısına ilişkin istatistiki kayıtlar hakkında bilgi alınamamıştır. Araştırmaya iletişim sorunu olmayan, sağlıklı bebeğe sahip, vajinal yolla veya sezaryen ile doğum yapmış, bebek bakımına engel olacak herhangi bir komplikasyon gelişmeyen, kendisine ulaşılabilen ve araştırmaya katılmayı kabul eden 406 anne katılmıştır.

Araştırmanın örneklemini evrenden gelişigüzel örnekleme ile seçilen, sezaryen veya vajinal yolla doğum yapmış anne oluşturdu. Örneklemin belirlenmesinde Çapık, Özkan ve Ejder Apay'ın (14) 'Loğusaların Doğum Sonu Konfor Düzeyleri ve Etkileyen Faktörlerin Belirlenmesi" adlı çalışmada elde edilen, araştırma kapsamındaki kadınların vajinal doğum sonrası konfor ölçeği toplam puan ortalaması $119.53 \pm 13.93$, sezaryen ile doğum yapanların toplam konfor ölçeği puan ortalamas1 $117.05 \pm$ 13.24 kullanılarak $\mathrm{t}$ testi için G-Power 3.10 programında etki gücü $\mathrm{d}=0,353$ hesaplanmış, grup oranları 1/1 alınarak \%95 güven aralığında $\alpha=0,05, \% 80$ güce ulaşmak için örneklem hacmi toplamda 406 anne olarak belirlenmiş ve araştırmanın örneklemini oluşturmasına karar verilmiştir.

Yapılan post hoc analizde çalışma kapsamında vajinal doğum yapan kadınların doğum sonrası konfor ölçeği toplam puan ortalamas1 109.29 \pm 9.57 , sezaryen ile doğum yapanların konfor ölçeği toplam puan ortalaması $111.08 \pm 8.80$ kullanılarak $t$ testi için G-Power 3.10 programında etki gücü $d=0,831$ hesaplanmış, $\% 95$ güven aralığında $\alpha=0,05$ ile araştırmanın gücü $\% 100$ olarak bulunmuştur.

Veri Toplama Araçları: Veri toplama aracı olarak kişisel bilgi formu ve Doğum Sonu Konfor Ölçeği (DSKÖ) kullanılmıştır.

Kişisel Bilgi Formu: Doğum yapan kadına ve doğum sonu özelliklerine ilişkin tanıtıcı özellikler yer almaktadır. Bireye ilişkin özellikler; yaş, eğitim durumu, çalışma durumu, gelir-gider durumu, aile tipine ait toplam 5 soru; kadınların doğum sonu özellikler; annelerin gebeliği isteme, doğum sayısı, doğum şekli, doğumda komplikasyon gelişme durumu, doğum sonu anne-bebek ilişskisinin sağlanma durumuna ilişkin toplam 5 sorudan oluşan toplam 10 soru bağımsız değişkenlerdir.

Doğum Sonu Konfor Ölçeği (DSKÖ): Doğum sonu konforu belirlemek amaciyla Karakaplan ve Yıldız (21) tarafından geliştirilmiş olup, 34 maddeden oluşmaktadır. "DSKÖ, 5'li likert tipi bir ölçektir. Her bir madde için geçerli olmak üzere "tamamen katılıyorum" (5 puan), ve "kesinlikle katılmıyorum" (1 puan) arasında puanlanmaktadır. Olumlu cümlelerde tamamen katıliyorum ifadesi en iyi konforu (5 puan), olumsuz cümlelerde ise düşük konforu (1 puan) göstermektedir. Bu doğrultuda ölçekten alınacak en düşük puan 34, en yüksek puan 170' dir. Ölçek fiziksel, psikospirütüel, sosyokültürel olarak üç alt boyuta sahiptir. Ölçekten alınan puanın artması doğum sonu konforun arttığını göstermektedir.

I. faktörde yer alanlar fiziksel ve bedensel algılar ile ilgili olanlardır ve ölçeğin fiziksel konfor alt boyutunu oluşturmuştur ( $1,2,4,6,8$, $11,12,13,14,16,17,21,24,26$ maddeler). II. faktörde yer alanlar manevi ve psikolojik bileşenlerdir ve ölçeğin psikospritüel konfor alt boyutunu oluşturmuştur $(5,7,10,15,18,19,20$, $23,25,31$. maddeler). III. faktörde yer alanlar kişilerarası, aile ve sosyal ilişkiler, finans ve destek sistemleri ile ilgili olanlardır ve ölçeğin sosyokültürel konfor alt boyutunu oluşturmuştur $(3,9,22,27,28,29,30,32,33,34$ maddeler). Olumsuz maddeler 5-1 şeklinde ters kodlanmıştır, $(4,6,8,9,10,12,13,16,17,21,22,26,27,28$, $29,30,33,34)$. Olumlu ifadeler normalde belirtilen ifadelendirme şekline göre 1-5 şeklinde kodlanmiştır $(1,2,3,5,7,11,14,15,18,19,20$, 23, 24, 25, 31, 32)." Ölçeğin Cronbach's alfa toplam DSKÖ için .78 olup (21), bu çalışmada .79 olarak belirlenmiştir.

Verilerin Toplanması: Veriler toplanmadan önce araştırmaya dâhil edilme kriterlerine uyan ve araştırmaya katılmayı kabul eden annelere, yapılacak olan araştırmaya ile ilgili açıklama yapılmıştır. Veriler araştırmacı tarafindan katılımcılardan hastanede yattığı kendi odalarında ve yanlarında soruları cevaplamalarını engelleyecek kişilerin bulunmadığ taburcu olacakları gün bilgilendirilmiş onam alındıktan sonra yüz yüze görüşme tekniği ile yaklaşık 30-35 dakikada toplanmıştır.

Verilerin Değerlendirilmesi: Araştırmada elde edilen verilerin analizinde SPSS (Statistical Package for Social Sciences) for Windows 24.0 programı kullanılmıştır. Kişisel özelliklere ilişkin verilerin değerlendirilmesinde frekans, yüzde ve ortalama değerleri, tanımlayıcı özelliklere ilişkin verilerin değerlendirilmesinde ise Croncbach alfa katsayısı, bağımsız örneklem t testi, MannWhitney-U testi, tek yönlü varyans analizi (ANOVA) ve Kruskall-Wallis varyans analizi kullanılmıştır. Normallik testi sonucunda, normal kabul edilen veri setinde parametrik, normal dağılım göstermeyen veri setinde ise non- 
parametrik testler kullanılmış ve veriler yorumlanmıştır. Kruskall-Wallis varyans analizinde fark saptanan gruplarda, MannWhitney U testi ileri analizi, varyans analizinde fark saptanan gruplarda LSD çoklu karşılaştırma testi kullanılmıştır (22).

Etik İlkeler: Araştırma için Muğla Sitkı Koçman Üniversitesi Bilimsel Araştırmalar ve Yayın Etiği Kurulu'ndan etik kurul (20.06.2016 tarihli ve Protokol no: 102 Karar no:102) izni, araştırmanın yapıldığı kurumdan da yazılı izin alınmıştır. Araştırmaya katılan kadınlardan yazılı ve sözlü onam alınmıștır.

\section{BULGULAR VE TARTIŞMA}

Araştırmaya katılan kadınların \%55.2'si 20-29 yaş grubunda, \%32.3'ü lise mezunu, \%64.3'ü ev hanımı, \%'53.2'sinin geliri giderine denk, \%97.5'i ise çekirdek aileye sahiptir. Kadınların \%81.8'i bu gebeliği istediğini, \%44.8'inin ilk çocuğu olduğu, \%63.5'inin sezaryenle doğum yaptı̆̆,$\% 91.9$ 'unda doğumda komplikasyon gelişmediği, \%87.9'unun doğum sonu anne-bebek ilişkisinin sağlandığ belirlenmiştir.

Tablo 1. Kadınların DSKÖ Toplam Puan ve Alt Boyut Puan Ortalamalarının Dağılımı

\begin{tabular}{lll}
\hline $\begin{array}{l}\text { Doğum Sonu } \\
\text { Konfor Ölçeği }\end{array}$ & $\overline{\mathbf{X}} \pm$ SS & Min-Max \\
\hline Fiziksel konfor & $38.68 \pm 10.75$ & $14-66$ \\
Psikospritüel konfor & $18.39 \pm 5.31$ & $10-34$ \\
Sosyokültürel konfor & $28.14 \pm 4.61$ & $16-41$ \\
Toplam DSKÖ & $\mathbf{1 1 0 . 4 2} \pm \mathbf{9 . 1 2}$ & $\mathbf{7 7 - 1 3 2}$ \\
\hline
\end{tabular}

Doğum yapan kadınların DSKÖ toplam puan ortalamasının $110.42 \pm 9.12$ olup, ölçek sonucuna göre orta düzeyde doğum sonu konforuna sahip oldukları saptanmıştır (Tablo 1). Bu sonuç, Çapık, Özkan, Ejder Apay'ın (14) ve Karakaplan'ın (23) yaptıkları çalışmalarla benzerlik göstermektedir. Araştırmada yeni doğum yapan kadınların DSKÖ toplam puan ortalamaları ile tanıtıcı özellikleri arasındaki ilişkiler incelendiğinde; toplam puan ile çalışma ve gelir durumu arasinda istatistiksel olarak anlamlı bir fark olduğu $(p<0.05)$, eğitim, yaş grubu ve aile tipi arasında ise istatistiksel olarak anlamlı bir fark olmadığ $(\mathrm{p}>0.05)$ belirlenmiştir (Tablo 2). Kadınların çalışma durumuna göre toplam DSKÖ puan ortalaması çalışmayan kadınlarda çalışanlara göre daha yüksek olduğu $111.80 \pm 8.29$ belirlenmiştir. Kadınların gelir-gider durumuna göre toplam DSKÖ puan ortalamas1 arasındaki farkın MWU çoklu analiz karşıllaştırma testine göre geliri giderinden az olanların diğer gruptakilerden daha yüksek puan ortalamasına sahip oldukları saptanmıştır ( $\mathrm{p}=0.013)$.

Kişisel özelliklerine göre alt boyutları karşılaştırıldığında; fiziksel alt boyut puan ortalaması ile annelerin aile tipleri arasindaki farkın istatistiksel olarak anlamlı olduğu $(\mathrm{p}<0.05)$, yaş grubu, eğitim, çalışma, gelir-gider durumu arasındaki farkın istatistiksel olarak anlamlı olmadığ1 ( $>>0.05)$ bulunmuştur (Tablo 2). Aile tipine göre fiziksel alt boyut puan ortalamaları incelendiğinde; geniş aileye sahip annelerin fiziksel alt boyut puan ortalamaları daha yüksek $45.00 \pm 7.80$ olduğu belirlenmiştir.

Psiko-spritüel alt boyut puan ortalamas1 ile kadınların gelir-gider durumu ve aile tipleri arasındaki farkın istatistiksel olarak anlamlı olduğu $(p<0.05)$, yaş grubu, eğitim, çalışma durumu arasındaki farkın istatistiksel olarak anlamlı olmadığ 1 ( $\mathrm{p}>0.05$ ) bulunmuştur (Tablo 2). Gelir-gider durumuna göre toplam psiko-spritüel alt boyut puan ortalaması arasındaki farkın MWU çoklu analiz karşılaştırma testine göre gelirigiderine denk olanlardan kaynaklandığı ve diğer gruptakilere göre en düşük puan ortalamasına sahip oldukları bulunmuştur $(\mathrm{p}=0.015)$. Aile tipine göre psiko-spritüel alt boyut puan ortalamaları incelendiğinde; geniş aileye sahip annelerin psiko-spritüel alt boyut puan ortalamaları daha yüksek $28.90 \pm 6.06$ olduğu belirlenmiştir.

Sosyo-kültürel alt boyut puan ortalamas ile kadınların gelir-gider durumu arasındaki farkın istatistiksel olarak anlamlı olduğu $(\mathrm{p}<0.05)$, yaş grubu, eğitim, çalışma durumu ve aile tipi arasındaki farkın istatistiksel olarak anlamlı olmadığı ( $>0.05$ ) bulunmuştur (Tablo 2). Gelirgider durumuna göre toplam sosyo-kültürel alt boyut puan ortalaması arasındaki farkın MWU çoklu analiz karşılaştırma testine göre gelirigiderinden az olanlardan kaynaklandığı ve diğer gruptakilere göre daha yüksek puan ortalamasına sahip oldukları saptanmıştır $(\mathrm{p}=0.028)$. 
Tablo 2. Doğum Yapan Kadınların Tanıtıcı Özellikleri ile DSKÖ Puan Ortalamalarının Karşılaştırılması

\begin{tabular}{|c|c|c|c|c|c|}
\hline \multirow{3}{*}{ Özellikler } & \multirow{3}{*}{$\mathbf{n}$} & \multicolumn{3}{|c|}{ ALT BOYUTLAR } & \multirow{2}{*}{$\begin{array}{c}\text { TOPLAM } \\
\text { DSKÖ }\end{array}$} \\
\hline & & Fiziksel & Psiko-spritüel & Sosyo-kültürel & \\
\hline & & $\overline{\mathbf{X}} \pm \mathbf{S S}$ & $\overline{\mathbf{X}} \pm \mathbf{S S}$ & $\overline{\mathbf{X}} \pm \mathbf{S S}$ & $\overline{\mathbf{X}} \pm \mathbf{S S}$ \\
\hline \multicolumn{6}{|l|}{ Yaş grubu } \\
\hline $15-19$ & 22 & $38.68 \pm 7.85$ & $20.86 \pm 6.99$ & $29.36 \pm 4.62$ & $113.90 \pm 5.78$ \\
\hline $20-29$ & 224 & $38.64 \pm 11.18$ & $18.09 \pm 5.25$ & $28.00 \pm 4.47$ & $110.32 \pm 8.87$ \\
\hline 30 ve üzeri & 160 & $38.68 \pm 10.75$ & $18.39 \pm 5.31$ & $28.14 \pm 4.61$ & $110.42 \pm 9.12$ \\
\hline Test ve p değgeri & & $\begin{array}{l}\mathrm{F}=.004 \\
\mathrm{p}=.996\end{array}$ & $\begin{array}{c}\mathrm{KW}=3.092 \\
\mathrm{p}=.213\end{array}$ & $\begin{array}{c}\mathrm{KW}=.2 .635 \\
\mathrm{p}=.268\end{array}$ & $\begin{array}{c}\mathrm{KW}=2.526 \\
\mathrm{p}=.283\end{array}$ \\
\hline \multicolumn{6}{|l|}{ Eğitim durumu } \\
\hline Okuryazar değil & 9 & $35.11 \pm 15.07$ & $21.11 \pm 7.11$ & $29.11 \pm 3.88$ & $115.55 \pm 6.69$ \\
\hline İlkokul mezunu & 88 & $37.69 \pm 10.72$ & $19.50 \pm 5.68$ & $28.59 \pm 4.77$ & $111.34 \pm 9.22$ \\
\hline Ortaokul mezunu & 85 & $38.56 \pm 9.36$ & $18.48 \pm 4.89$ & $28.28 \pm 4.04$ & $112.03 \pm 8.00$ \\
\hline Lise mezunu & 131 & $38.53 \pm 10.96$ & $17.94 \pm 5.47$ & $28.03 \pm 4.41$ & $110.21 \pm 8.60$ \\
\hline $\begin{array}{l}\text { Önlisans/Lisans } \\
\text { mezunu }\end{array}$ & 93 & $40.27 \pm 11.20$ & $17.64 \pm 4.76$ & $27.63 \pm 5.26$ & $107.90 \pm 10.31$ \\
\hline Test ve p değgeri & & $\begin{array}{l}F=.956 \\
p=.432\end{array}$ & $\begin{array}{c}\mathrm{KW}=8.148 \\
\mathrm{p}=.086\end{array}$ & $\begin{array}{c}\mathrm{KW}=.757 \\
\mathrm{p}=.860\end{array}$ & $\begin{array}{c}\mathrm{KW}=4.020 \\
\mathrm{p}=.259\end{array}$ \\
\hline \multicolumn{6}{|l|}{ Çalışma durumu } \\
\hline Çalışanlar & 145 & $39.33 \pm 11.02$ & $17.91 \pm 18.66$ & $28.64 \pm 4.99$ & $107.95 \pm 10.01$ \\
\hline Çalışmayanlar & 261 & $38.31 \pm 10.59$ & $18.66 \pm 5.51$ & $27.85 \pm 4.37$ & $111.80 \pm 8.29$ \\
\hline Test ve p dĕgeri & & $\begin{array}{l}t=.916 \\
p=.366\end{array}$ & $\begin{array}{c}\text { MWU }=17639.0 \\
p=.256\end{array}$ & $\begin{array}{c}\mathrm{MWU}=16849.0 \\
\mathrm{p}=.067\end{array}$ & $\begin{aligned} \text { MWU } & =14579.50 \\
\mathbf{p} & =\mathbf{. 0 0 0}\end{aligned}$ \\
\hline \multicolumn{6}{|l|}{ Gelir- gider durumu } \\
\hline Geliri giderinden $\mathrm{az}$ & 118 & $38.10 \pm 9.45$ & $19.67 \pm 5.75$ & $29.04 \pm 4.56$ & $111.73 \pm 9.40$ \\
\hline Geliri giderine denk & 216 & $38.22 \pm 10.67$ & $17.81 \pm 5.26$ & $27.63 \pm 4.18$ & $110.60 \pm 8.29$ \\
\hline Geliri giderinden fazli & 72 & $41.01 \pm 12.65$ & $18.05 \pm 4.35$ & $28.18 \pm 5.63$ & $107.76 \pm 10.50$ \\
\hline Test ve p değeri & & $\begin{array}{c}F=2.074 \\
p=.127\end{array}$ & $\begin{array}{c}\mathrm{KW}=8.393 \\
\mathbf{p}=\mathbf{0 1 5}\end{array}$ & $\begin{array}{c}\mathrm{KW}=7.962 \\
\mathbf{p}=\mathbf{0 1 9}\end{array}$ & $\begin{array}{c}\mathrm{KW}=8.249 \\
\mathbf{p}=\mathbf{. 0 1 6}\end{array}$ \\
\hline \multicolumn{6}{|l|}{ Aile tipi } \\
\hline Çekirdek aile & 396 & $38.52 \pm 10.77$ & $18.30 \pm 5.30$ & $28.12 \pm 4.57$ & $110.51 \pm 9.08$ \\
\hline Geniş aile & 10 & $45.00 \pm 7.80$ & $28.90 \pm 6.06$ & $28.90 \pm 6.06$ & $107.00 \pm 10.54$ \\
\hline Test ve p dĕgeri & & $\begin{array}{r}t=-1.888 \\
\mathbf{p}=\mathbf{. 0 2 8}\end{array}$ & $\begin{aligned} & \text { MWU }=1214.5 \\
& \mathbf{p}=. \mathbf{0 3 6}\end{aligned}$ & $\begin{array}{c}\text { MWU }=1723.5 \\
p=.483\end{array}$ & $\begin{array}{c}\text { MWU }=1604.5 \\
p=.305\end{array}$ \\
\hline
\end{tabular}

DS dönem; kadın için çok önemlidir. Bu dönemde anne bakıma, bilgiye ve desteğe ihtiyaç duyar. $\mathrm{Bu}$ süreçte kadın fizyolojik ve psikolojik değişikliklere uğrar, yeni rol ve sorumluluklar üstlenir, bebeğini kabullenir ve kendine ve bebeğine bakım verebilmesi için gerekli olan bilgi ve becerileri kazanır. Bunun için bu dönemde annenin ve bebeğin bakım ihtiyaçlarının belirlenmesi, danışmanlık verilmesi ve konforlu sağlık bakımı verilmesi oldukça önem arz etmektedir (11). Kadınların çalışma ve gelir-gider durumu ile DSKÖ toplam puan ortalamas1 arasındaki farkın istatistiksel olarak anlamlı olup $(p<0.05)$, çalıșanların, gelirinin giderinden fazla olan kadınların DSKÖ toplam puan ortalaması daha düşüktür. Çalışma ve gelir-gider durumu birbirini etkileyen faktörlerdir (24).
Aile tipi dışında fiziksel alt boyutu diğer değişkenlerin etkilememesinin nedeni hastane ortamının tüm anneler için aynı olması ve DS dönemde oluşabilecek fiziksel rahatsızlıkların (karın ağrısı, gaz vb.) bu değişkenlerden etkilenmediğini, sağlık bakım hizmetlerinin iyi olduğunu düşündürebilir. Kadınların gelir-gider durumu, aile tiplerine göre psikospritüel alt boyut puan ortalaması arasındaki farkın anlamlı olduğu saptanmıştır. Psikospritüel konfor mental, psikolojik ve manevi bileşenlerini içerir (25). Geniş aile tipinde, geliri- giderinden az olan ve çalışmayan annelerin psikospritüel konfor alt boyut puan toplamlarının yüksek olması, annebebeğin konforunun sağlanmasında etkili olabileceği düşünülebilir. 
Tablo 3. Doğum Yapan Kadınların Obstetrik Özelliklerine Göre DSKÖ Puan Ortalamalarının Karşılaştırılması

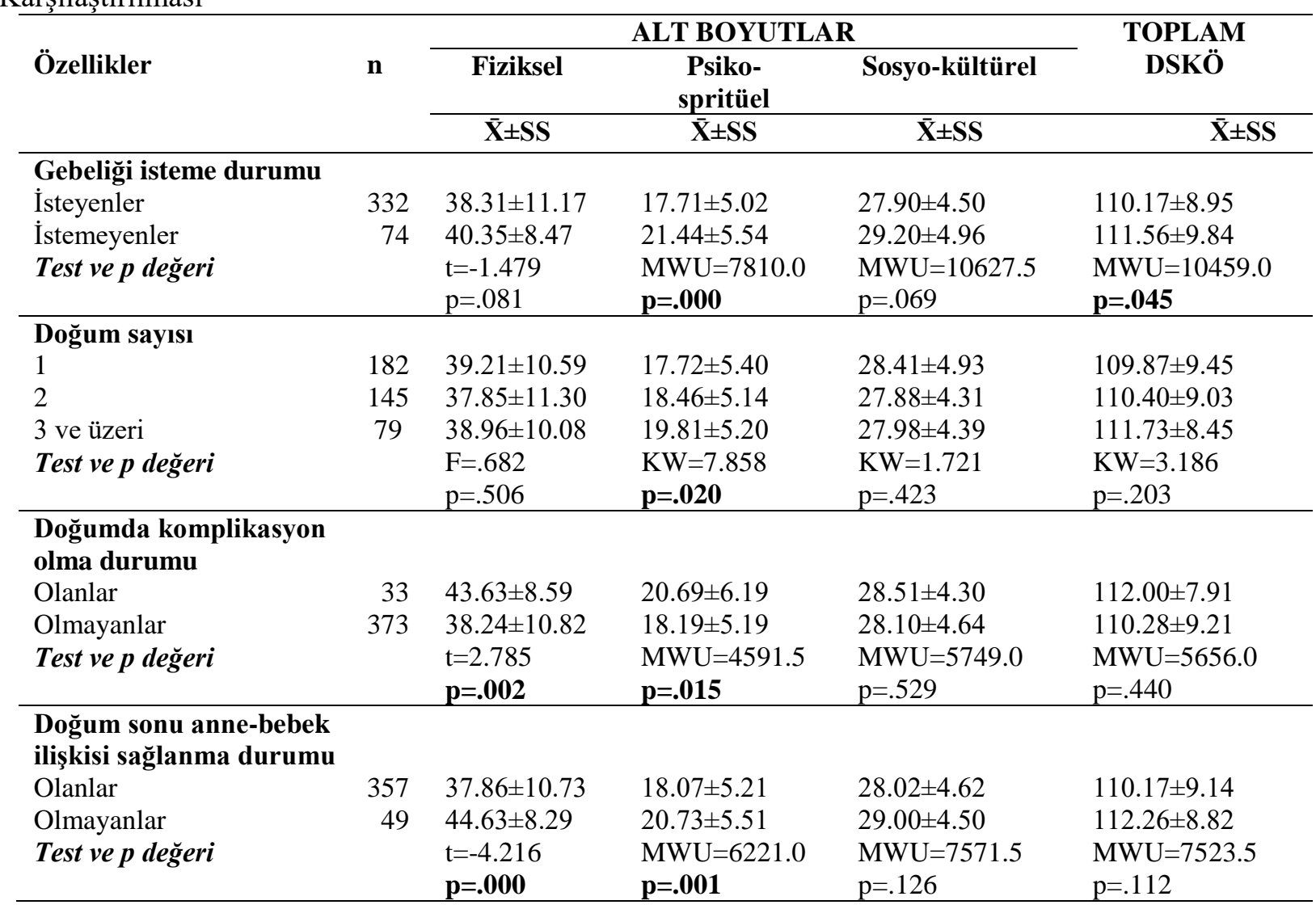

Yeni doğum yapan kadınların obstetrik özelliklerine göre DSKÖ toplam puan ortalamaları karşılaştıııldığında; kadınların gebeliği isteme durumları arasında istatistiksel olarak anlamlı fark olduğu $(\mathrm{p}<0.05)$, diğer değișkenler ile gruplar arasında ise anlamlı fark olmadığ $(p>0.05)$ belirlenmiştir. Ölçeğin alt boyutları incelendiğinde; fiziksel alt boyut toplam puan ile doğumda komplikasyon olma ve doğum sonu anne-bebek ilişkisinin sağlanması durumu arasında istatistiksel olarak anlamlı bir fark olduğu $(\mathrm{p}<0.05)$, gebeliği isteme durumu ve doğum sayısı arasında ise istatistiksel olarak anlamlı bir fark olmadığ $1(\mathrm{p}>0.05)$ belirlenmiştir. Fiziksel alt boyut toplam puan ortalamasinin doğumda komplikasyon olanların olmayanlara göre daha yüksek olduğu 43.63 \pm 8.59 , doğum sonu anne-bebek ilişkisinin sağlanmayanların sağlananlara göre daha yüksek olduğu $44.63 \pm 8.29$ saptanmıştır (Tablo 3). Psiko-spritüel alt boyut puan ortalaması ile kadınların gebeliği isteme durumu, doğum sayıs1, doğumda komplikasyon olma ve doğum sonu anne-bebek ilișkisinin sağlanması durumu arasında istatistiksel olarak anlamlı bir fark olduğu $(\mathrm{p}<0.05)$ bulunmuştur (Tablo 3). Psiko-spritüel alt boyut puan ortalamas1 gebeliği isteyen annelerin istemeyenlere göre
17.71 \pm 5.02 daha düşük düzeyde, doğum sonu komplikasyon olanlarda olmayanlara göre $20.69 \pm 6.19$ daha yüksek, doğum sonu anne-bebek ilişkisi sağlanan annelerin sağlanmayanlara göre $18.07 \pm 5.21$ daha düşük düzeyde olduğu belirlenmiştir (Tablo 3). Annelerin doğum sayısına göre toplam psiko-spritüel alt boyut puan ortalaması arasındaki farkın MWU çoklu analiz karşılaştırma testine göre 3 ve üzerinde doğum yapan annelerden kaynaklandığ 1 ve diğer gruptakilere göre daha yüksek puan ortalamasına sahip oldukları saptanmıştır $(\mathrm{p}=0.020)$. Sosyokültürel alt boyut puan ortalaması ile değişkenler arasında istatistiksel olarak anlamlı fark olmadığ saptanmıştır ( $\mathrm{p}>0.05$, Tablo 3$)$.

Uygun zamanda isteyerek gebelik ve sağl1klı bebeğe sahip olma anne, babalar hatta yakın aile bireyleri ve arkadaşları için büyük mutluluğa neden olmaktadır. İstenmeden gebelik, çocuk sayısının istenmeden artması ve sağlıklı bebeğe sahip olmama gibi faktörler gebelik, doğum ve DS dönemlerde psikolojik ve sosyal sorunlara neden olabilmekte, bu da annelerin DS döneme uyumunu zorlaştırmakta ve psikospritüel konforlarını etkileyebilmektedir. Yapılan çalışma sonuçlarında kadınların gebeliğini isteme durumları ile psikospritüel puan ortalaması 
arasında istatistiksel olarak anlamlı fark olduğu belirtilmektedir $(14,25)$. Sis Çelik ve Çelik' in (26) yaptıkları çalışmada kadınların şimdiki gebeliğini isteme duruma göre doğum sonu konfor düzeyleri incelendiğinde; şimdiki gebeliğin istenme durumuna göre fiziksel konfor alt boyutu ve toplam puan ortalamaları arasındaki farkın istatistiksel olarak anlamlı olduğu saptanmıştır $(\mathrm{p}<0,05)$. Bu sonuçlar çalışma bulgularıla benzerlik göstermemektedir. Gebeliği isteyen annelerin DSKÖ fiziksel, psiko-spritüel ve sosyokültürel alt boyut puan ortalamalarının düşük olmas1, annelerin konfor konusunda beklentilerinin yüksek olduğunu düşündürebilir. Sis Çelik ve Çelik'in (26) yaptıkları çalışmada kadınların doğum sonu yaşadıkları sorunlara göre DSKÖ toplam puan ortalamalar1 karşılaş̧ırıldığında; annelerin doğum sonu dönemde yaşadıkları tüm sorunlar ile DSKÖ puan ortalamaları arasındaki farkın anlamlı olduğu $(\mathrm{p}<0.05)$, komplikasyon olanların olmayanlara göre DSKÖ puan ortalamalarının daha düşük olduğu belirlenmiştir. Bu sonuç çalışma bulguları ile farklılık göstermektedir.

DS dönem annelerde fiziksel, duygusal ve sosyal değişikliklerin oluştuğu önemli bir dönemdir. Anneler bu dönemde, anatomik ve fizyolojik değiş̧iklikler, annelik rolü ve sorumluluklar üstlenir ve bu anne için zor bir süreçtir. DS dönemde anne, bebek bakımı konusunda zorlanabilir (25). Ayn zamanda bu dönemde anneler duygusal olarak çok hassastır ve çeşitli duygu durum bozuklukları gelişebilir. $\mathrm{Bu}$ dönem bebeğin fizyolojik olarak homeostatik dengesini oluşturmaya çalıştığı dönemdir. Bunu da ancak annesinin desteğiyle oluşturabilir. $\mathrm{Bu}$ nedenle doğumdan hemen sonra anne ve bebek için uyum sürecinin başlaması oldukça önemli varsayılmaktadır $(27,28)$. Yapılan bir derlemede 1925 anne ve bebekleriyle yapılan 30 çalışma sonucunda; erken anne bebek ilişkisinin sağlandığı bebeklerin anneleriyle daha çok etkileşim kurduğunu ve daha az ağladığını belirlemiş̧lerdir (29). Çalışmada DS dönemde katılımcıların büyük çoğunluğunun anne bebek ilişkisinin sağlanması ve anne bebek ilişkisinin sağlanma durumu ile annelerin fiziksel ve psikospritüel boyut puan ortalamas1 arasinda istatistiksel olarak anlamlı fark olması, annelerin bu konularda bakım gereksinimlerinin karşılandığını düşündürebilir, ancak anne-bebek ilişkisi sağlanamayan annelerin DSKÖ ve alt boyutlarının toplam puan ortalamalarının daha yüksek olması sezaryenle doğum yapan annelerin fazla olmasından kaynaklanabilir. Doğum yapan kadınların doğum şekline göre DS konfor düzeyleri karşılaştırıldığında; DSKÖ toplam puan ortalamasının normal vajinal doğum yapan kadınların 109.29 \pm 9.57 , sezaryenle doğum yapan kadınların $111.08 \pm 8.80$ olduğu ve aralarındaki farkın istatistiksel olarak anlamlı olmadığ $(\mathrm{p}>0.05)$ belirlenmiştir. Annelerin doğum şekli ile ölçeğin fiziksel ve psiko-spritüel alt boyutları arasında istatistiksel olarak anlamlı fark $(\mathrm{p}<0.05)$ bulunurken, sosyo-kültürel alt boyut arasında istatistiksel olarak anlamlı fark $(\mathrm{p}>0.05)$ saptanmamıştır. Sezaryenle doğum yapan kadınlarda fiziksel alt boyut toplam puan ortalamas1 $42.50 \pm 9.43$, psiko-spritüel alt boyut toplam puan ortalamas1 $19.25 \pm 5.24$ ve sosyokültürel alt boyut toplam puan ortalamas1 $28.44 \pm 4.42$ daha yüksek olarak belirlenmiş̧ir (Tablo 4). Sis Çelik ve Çelik'in (26) yaptıkları çalışmada doğum yapan annelerin doğum şekline ve aldıkları anestezi türüne göre doğum sonu konfor düzeyleri incelendiğinde; DSKÖ'nün alt boyutları ve toplam puan ortalamalarına göre gruplar arasındaki farkın istatistiksel olarak anlamlı olduğu belirlenmiştir $(\mathrm{p}<0.05)$. Fiziksel ve psiko-spritüel alt boyut bulguları çalışma sonuçlarını desteklemektedir. Karakaplan'ın (23) çalışmasında vajinal doğum yapan lohusaların fiziksel konforunun daha yüksek olduğu, Çapık ve ark.'nın (30) çalışmasında ise vajinal doğum yapanlarda fiziksel ve sosyokültürel doğum sonu konforun sezaryen olanlara göre daha yüksek olduğu belirtilmiştir. Pınar ve ark. (1) yaptıkları çalışmada normal doğum yapanların doğum sonu konfor düzeylerinin sezaryen olan annelerden daha yüksek olduğunu bulmuşlardır. Bu bulgular çalışma sonuçları ile farklılık göstermektedir. 
Tablo 4. Doğum Yapan Kadınların Doğum Şekline Göre Doğum Sonu Konfor Düzeylerinin Karşılaştırılması

\begin{tabular}{|c|c|c|c|c|c|}
\hline Doğum Şekli & $\mathbf{n}$ & $\begin{array}{c}\text { Fiziksel } \\
\overline{\mathbf{X}}_{ \pm \text {SS }} \\
\end{array}$ & $\begin{array}{c}\text { ALT BOYUTLAR } \\
\text { Psiko-spritüel } \\
\overline{\mathbf{X}}_{ \pm \mathrm{SS}} \\
\end{array}$ & $\begin{array}{c}\text { Sosyo-külttürel } \\
\overline{\mathbf{X}}_{ \pm \text {SS }} \\
\end{array}$ & $\begin{array}{c}\text { TOPLAM } \\
\text { DSKÖ } \\
\overline{\mathbf{X}} \pm \text { SS } \\
\end{array}$ \\
\hline $\begin{array}{l}\text { Doğum Şekli } \\
\text { Normal Vajinal Doğum } \\
\text { Sezaryen } \\
\text { Test ve p değeri }\end{array}$ & $\begin{array}{l}148 \\
258\end{array}$ & $\begin{array}{l}32.02 \pm 9.61 \\
42.50 \pm 9.43 \\
t=-10.700 \\
\mathbf{p}=.000\end{array}$ & $\begin{array}{l}16.90 \pm 5.13 \\
19.25 \pm 5.24 \\
t=-4.373 \\
\mathbf{p}=.000\end{array}$ & $\begin{array}{l}27.60 \pm 4.89 \\
28.44 \pm 4.42 \\
t=-1.788 \\
p=.075\end{array}$ & $\begin{array}{l}109.29 \pm 9.57 \\
111.08 \pm 8.80 \\
t=-1.910 \\
p=.057\end{array}$ \\
\hline
\end{tabular}

Kolcaba'ya göre rahatlık kelimesi Latince'de "daha fazla kuvvetlendirmek, güçlendirmek" anlamında olan "confortare" sözcüğünden gelmektedir. $\mathrm{Bu}$ anlamda, "güçlendirmek, cesaretlendirme, teşvik etme, yardım etme, sikıntıdan kurtarma" anlamina gelmektedir $(18,25)$. Annenin DS döneme uyumunun ve konforunun sağlanmasında doğum şekli çok önemlidir. Fizyolojik konfor; bedensel duyular ve fizyolojik sistemlerdeki işleyişle ilgili dinlenme ve gevşeme, beslenme ve homeostazis, barsak fonksiyonunun devamlılığ faktörleri ele almaktadır. Homeostatik mekanizmalar bireyin fiziksel konforunu etkiler $(17,25)$. Ağrı, fiziksel konforun oluşturulmasında önemli bir faktördür (31). Sezaryenle DS ağn gibi olumsuz faktörler normal vajinal yolla doğum yapan annelerin konforunu daha olumsuz etkileyebilmektedir (32). Kadınlarda isteğe bağl1 sezaryen oranı yüksek olmasına rağmen, vajinal doğum yapan kadınların memnuniyet oranlarının daha yüksek olduğu belirtilmektedir $(30,33)$. Yapılan bazı çalışmalarda ise kadınlarda isteğe bağlı sezaryen oranı yüksek olmasına rağmen, vajinal doğum yapan annelerin fiziksel memnuniyetlerinin daha yüksek olduğu bildirilmektedir $(1,14,23)$. Bu çalışmada da sezaryenle doğum yapan annelerin yüksek oranda olması çalışma sonuçları ile benzerlik gösterirken DS dönemde bu annelerin fiziksel, psiko-spritüel ve sosyo-kültürel konfor düzeyinin yüksek olması farkl1lık göstermektedir. Bu sonucun sezaryenle doğumun yüksek oranda isteğe bağl1 olabileceğinden, annelerin ağrı kontrollerinin iyi yönetilmesinden ve anne-bebek bakımına hasta refakatçilerinin de destek olmasından annelerin konfor beklentilerinin karşılanmasına katkısı olduğu düşündürebilir.

\section{Araştırmanın Sınırlılıkları}

$\mathrm{Bu}$ araştırma; DSKÖ kendini bildirim ölçeği olduğundan veriler gözlem yoluyla belirlenmemiş annelerin ifadeleri doğru kabul edilerek toplanmıştır. Ayrıca araştırmanın verileri sadece araştırmaya katılan annelerin doğum sonrası konfor düzeyleri ile sınırlı olduğundan tüm annelere genellenemez.

\section{SONUÇ VE ÖNERILLER}

Doğum yapan kadınların orta düzeyde konfora sahip oldukları saptanmıştır. Kadınların tanıtıc1 özelliklerinden çalışma ve gelir durumunun DSKÖ toplam puanını, aile tipinin fiziksel konfor düzeyini, gelir- gider durumları ve aile tiplerinin psiko-spritüel konfor düzeyini, gelir durumunun sosyo-kültürel konfor düzeyine etkisi olduğu saptanmıştır.

Obstetrik özelliklerden kadınların gebeliği isteme durumunun DSKÖ toplam puanını; annelerin doğumda komplikasyon oluşması durumu ve anne-bebek ilişkisinin sağlanması durumunun fiziksel konforu; gebeliği isteme, doğum sayısı, doğumda komplikasyon oluşması ve anne-bebek ilişkisinin sağlanması durumunun psiko-spritüel konforu etkileyen faktörler olarak belirlenmiștir. Kadınların doğum şeklinin fiziksel ve psikospritüel konfor düzeyini etkilediği, sezaryenle doğum yapanların konfor düzeylerinin daha yüksek olduğu saptanmıştır.

$\mathrm{Bu}$ sonuçlar doğrultusunda; annelerin DS konforunu artırmak için, hemşirelerin bakım planını düzenlerken annelerin fiziksel, psikospritüel ve sosyo-kültürel konfor bakım gereksinimlerini de göz önünde bulundurmaları, bakım sonuçlarını sürekli değerlendirmeleri, hasta memnuniyetinin artırilmasinda ve konfor konusunda hastane koşullarının iyileştirmesinde gerekli girişimlerde bulunmaları ve hastane ortamında farkındalık oluşturmaları önerilebilir. Ayrıca annelere konfor kuramına dayalı bakımın devamlılığının sağlanabilmesi için sürekli hizmet içi eğitimlerin yapılması, bu konuda araştırmaların farklı bölgelerde de yapılması faydalı olabilir.

\section{Teşekkür}

Araştırmayı yapmak için destek olan Muğla Sitkı Koçman Üniversitesi Eğitim Araştırma Hastanesi Kadın Doğum Kliniği' nde çalışan ebe, hemşire ve doktorlarına, ayrıca araştırmaya katılan annelere teşekkür ederim. 
Anadolu Hemşirelik ve Sağlık Bilimleri Dergisi Journal of Anatolia Nursing and Health Sciences

Çıkar Çatışması: Araştırmada çıkar çatışması yoktur.

\section{KAYNAKLAR}

1. Pınar G, Doğan N, Algıer L, Kaya N, Çakmak F. Annelerin doğum sonu konforunu etkileyen faktörler. Dicle Tıp Dergisi 2009; 36(3): 184-90.

2. Taşkın L. Doğum ve Kadın Sağlığı Hemşireliği, Sistem Ofset Matbaacılik, Ankara, 2016: 534.

3. Gürcüoğlu EA, Vural G. Annelerin doğum sonu dönemde hastanede verilen ebelik/hemşirelik bakımından memnuniyetleri. Gazi Medical Journal 2017; 29(1): 34-40.

4. Çelik AS, Türkoğlu N, Pasinlioğlu T. Annelerin doğum sonu yaşam kalitesinin belirlenmesi. Anadolu Hemşirelik ve Sağlık Bilimleri Dergisi 2014; 17(3): 151-7.

5. Mermer G, Bilge A, Yücel Ü, Çember E. Investigation of perceptions of social support level in pregnancy and postpartum period. Journal of Psychiatric Nursing 2010; 72;1(2):71-6.

6. Dennis CL, Chung-Lee L. Postpartum depression help-seeking barriers and maternal treatment preferences: A qualitative systematic review. Birth 2006; 33(4): 323-31.

7. Doğaner G, Bekar M. Vajinal yolla doğum yapan kadınların erken postpartum dönemde kendisinin ve yeni doğanın bakımına yönelik yaşadıkları sorunların belirlenmesi. Sağlık ve Toplum Dergisi 2006; 16(4): 130-5.

8. Güneri SE. Postpartum erken dönem kanıta dayalı uygulamalar. Gümüşhane Üniversitesi Sağlık Bilimleri Dergisi 2015; 4(3): 482-96.

9. İşgüder ÇK, Bulut YE, Yılmaz G, Doğru HY, Özsoy AZ, Başol N. Kliniğimizde 2014-2016 y1lları arasında sezaryen oranı ve endikasyonları. Jinekoloji- Obstetrik ve Neonatoloji Tıp Dergisi 2017; 14(4): 168-71.

10. Atıcı İ, Gözüm S. Postpartum erken dönemde lohusalara verilen sağlık eğitiminin postpartum problem ve anksiyeteleri üzerine etkileri. Hacettepe Üniversitesi Hemşirelik Yüsekokulu Dergisi 2000;8(2):77-90.

11. Balkaya NA. Postpartum dönemde annelerin bakim gereksinimleri ve ebe-hemşirenin rolü. Cumhuriyet Üniversitesi Hemşirelik Yüksekokulu Dergisi 2002;6(2):42-9.

12. Bağc1 S, Altuntuğ K. Problems experienced by mothers in postpartum period and their associations with quality of life. Journal of Human Sciences 2016; 13(2), 3266-79.

13. Tezel A, Gözüm S. Postpartum dönemde kadınlarda görülebilen depresif belirtiler ve hemşirelik bakımı. Hacettepe Üniversitesi Hemşirelik Yüksekokulu Dergisi 2005; 12(2): 628.

14. Çapık A, Özkan H, Ejder Apay S. Loğusaların doğum sonu konfor düzeyleri ve etkileyen faktörlerin belirlenmesi. Dokuz Eylül Üniversitesi
2020; 23(3): 351-360

DOI: 10.17049 /ataunihem.484941

Yazar Katkısı: Fikir ve tasarım; F. B.; Veri toplama; F. B.; Veri analizi; F. B.; Yazım ve eleştirel inceleme; F. B.

Hemşirelik Yüksekokulu Elektronik Dergisi 2014; 7(3): 186-92.

15. Fenwick J, Barclay L, Schmied V. Struggling to mother: A consequence of inhibitive nursing interactions in the neonatal nursery. The Journal of Perinatal Neonatal Nursing 2001; 15(2): 49-64.

16. Kolcaba K. Comfort Theory and Practice: A Vision for Holistic Healt Care and Research. New York: Springer Publish Company. 2003.

17. Kolcaba K, Dimarco M. A Comfort theory and its application to pediatric nursing. Pediatric Nursing 2005; 31(3): 187-94.

18. Erdemir F, Çırlak A. Rahatlık kavramı ve hemşirelikte kullanımı. Dokuz Eylül Üniversitesi Hemşirelik Yüksekokulu Elektronik Dergisi 2013; 6(4):224-30.

19. Acar R, Aygin K. Orak hücre hastalığına bağlı akut göğüs sendromu'nun konfor kuramına göre değerlendirilmesi ve hemşirelik bakımı: Olgu sunumu. Online Türk Sağlık Bilimleri Dergisi 2016; 1(1):36-43.

20. Erkaya R, Türk R, Sakar T. Determining comfort levels of postpartum women after vaginal and caesarean birth. Procedia-Social and Behavioral Sciences 2017; 237:1526-32.

21. Karakaplan S, Yildız H. Doğum Sonu Konfor Ölçeği geliştirme çalışması. Maltepe Üniversitesi Hemşirelik Bilim ve Sanatı Dergisi 2010; 3(1): 55 65.

22. Çimen M. Fen ve sağlık bilimleri alanlarında spss uygulamalı veri analizi. Palme Yayıncılık, Yayın No: 905, ISBN: 978-605-355-366-3. Sihhiye, Ankara. 2015.

23. Aksoy Derya Y, Pasinlioğlu T. The effect of nursing care based on comfort theory on women's postpartum comfort levels after caesarean sections. International Journal of Nursing Knowledge 2017; 28(3): 138-44.

24. Bilgin NÇ, Bedriye AK, Potur DC, Ayhan F. Doğum yapan kadınların doğumdan memnuniyeti ve etkileyen faktörler. Sağlık Bilimleri ve Meslekleri Dergisi 2018; 5(3): 342-52

25. Kolcaba K, Kolcaba R. An analysis of the concept of comfort. Journal of Advanced Nursing 1991; 16(11): 1301-10.

26. Sis Çelik A, Çelik EC. Doğumun şekli ve doğumda alınan anestezi türü doğum sonu konforu etkiler mi? Hemşirelik Akademik Araştırma Dergisi 2020; 6(1):97-108.

27. Güleşen A, Yıldız D. Erken postpartum dönemde anne bebek bağlanmasının kanıta dayalı uygulamalar ile incelenmesi. Türk Silahli Kuvvetler Koruyucu Hekimlik Bülteni 2013; 12(2): 177-82.

28. Can G. Anne -Yenidoğan Bağının Önemi. Ed: Kişi A. Ben Hasta Değilim -Çocuk Sağlığı ve 


\section{Birgili}

Hastalıklarının Psikososyal Yönü. Nobel Tıp Kitabevi, 1999; 17-21.

29. Moore ER, Anderson GC, Bergman N. Early skinto-skin contact for mothers and their healthy newborn infants. Cochrane Database of Systematic Reviews 2012; 16: CD003519

30. Çapık A, Sakar T, Yıldırım N, Karabacak K, Korkut M. Annelerin doğum şekline göre doğumdan memnuniyet durumlarının belirlenmesi Anadolu Hemşirelik ve Sağlık Bilimleri Dergisi 2016; 19(2): 92-9.

31. Wilson L, Kolcaba K. Practical application of comfort theory in the perianesthesia setting.
Journal of Perianesthesia Nursing 2004; 19(3): 164-73.

32. Mirzaei K, Oladı GS, Mousavı BM, Ziaee M. Mother's satisfaction of postpartum care and its relationship with midwifery care at Urban Health Centers, Mashhad, Iran. Journal of Midwifery \& Reproductive Health 2016; 4(3): 679-88.

33. Maharlouei N, Rezaianzadeh A, Hesami E, Moradi F, Mazloomi E, Joulaei H, et al. The preference of iranian women to have normal vaginal or cesarean deliveries. Journal of research in medical sciences: the official journal of Isfahan University of Medical Sciences 2013; 18(11): 94350 . 